\section{REDPOLLS ATTRACTED TO A LURE}

CHRIS SIDDLE, 8927 116th Avenue, Fort St. John, British Columbia. V1J $2 Y 2$

At 1130 h, 14 January 1984 (a calm, overcast day of about minus $20^{\circ} \mathrm{C}$ ), Joan Johnston and I were attempting to attract an immature Snowy Owl along a road bordering a stubble field about $8 \mathrm{~km}$ northwest of Fort St. John, British Columbia. Our lure was a frozen vole (Microtus sp.) tied to the end of approximately $50 \mathrm{~m}$ of fishing line and cast by rod over the snow. Joan was about $30 \mathrm{~m}$ from the owl which was perched atop a hydro pole. She had cast the dead mouse along the weedy edge when, to our amazement, instead of attracting the owl, we "got" a flock of about 30 Redpolls, mostly Hoary Redpolls, with at least 2 Common Redpolls noted for sure. The finches suddenly appeared in a nearby patch of willows and dropped down singly or in little groups of two to five birds to land on weeds or on the snow close to the lure. The birds vocalized very frequently and followed the mouse as Joan reeled it in. As each bird would make one to six investigations, a dramatic flurry of redpolls appeared to follow the mouse.

Joan cast a second time and as she reeled in the frozen rodent, down fluttered at least 15 redpolls, again in pairs or trios. This time the Snowy Owl left its perch to make a single pass, flying over us at about $6 \mathrm{~m}$. Strangely, the entire flock of redpolls left the lure and, joined by 30 more from the willows, flew after the Snowy Owl, circling around it once that it had landed several telephone poles away from us. It was quite apparent to both of us that the redpolls were following or pursuing the owl, and not merely flying in the same direction.
We continued casting for another 15 minutes, during which time about 10 to 15 redpolls, mostly Hoaries, would flutter about the lure, always watching it as it was jerked through the grass and over the snow.

By $1200 \mathrm{~h}$ we were attracting only three or four Hoary Redpolls so we quit. The bulk of the flock had flown elsewhere.

It is difficult to describe the intentness of the finches' interest when they were first attracted to the lure. Although none landed on the dead mouse, several got within 3 or $4 \mathrm{~cm}$ of it. All birds appeared to watch it intently. Of further interest is the contrast between the tameness of these birds when they were investigating the lure, sometimes fluttering right beside us, to their wariness of an hour before when I had tried to photograph them feeding along the same road.

Robert Nero reported a similar experience he had with a Downy Woodpecker that twice inexplicably investigated his artificial lure. ${ }^{1} \mathrm{I}$, too, am at a loss to explain the interest in lures shown by woodpeckers or redpolls.

'NERO, ROBERT W. 1983. Downy Woodpecker shows investigative behaviour to artificial mouse. Blue Jay. 41(3):168.

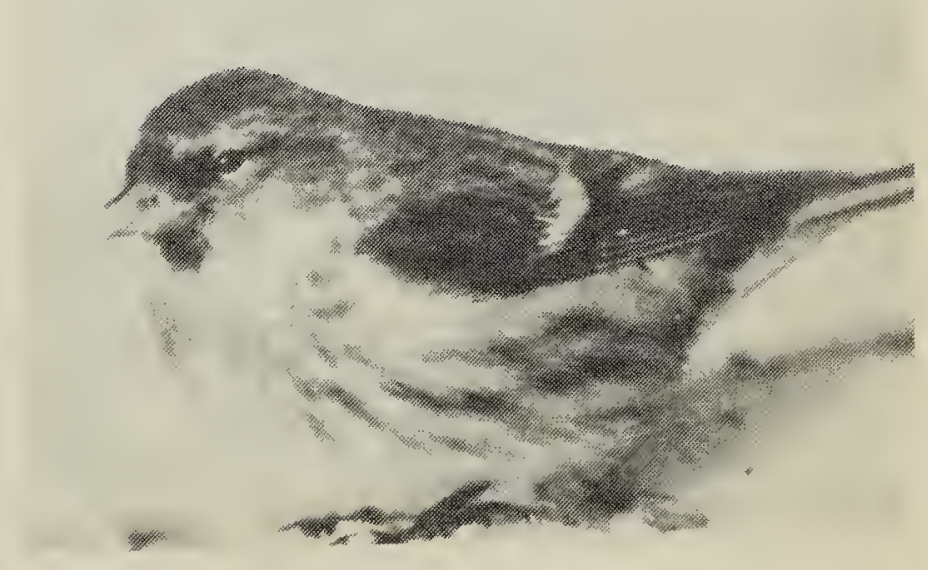

Common Redpoll.

Sheina Wait 